\title{
An Investigation of The Income Smoothing Behavior of Growth and Value Firms (Case Study: Tehran Stock Exchange Market)
}

\author{
Mohammad Namazi \\ Professor of Accounting, Shiraz University-Iran \\ Tel: 98-917-118-4375 E-mail:mnamazi@rose.shirazu.ac.ir \\ Ehsan Khansalar \\ $\mathrm{PhD}$ in Accounting, University of Sussex- England \\ Tel: 98-917-300-0557Ｅ-mail: ehsan@khansalar.com
}

Received: June 26, 2011

Accepted: July 12, 2011

doi:10.5539/ibr.v4n4p84

\begin{abstract}
The major objective of this study is to investigate the income smoothing behaviour of two different types of firms value and growth - in the Tehran Stock Exchange (TSE) Market.

All firms listed in the TSE between 2003 and 2007 were examined using the Jones Model to investigate their income smoothing behaviours. Using the Jones model, the discretionary part of accruals was investigated. The results of this study revealed that growth firms tend to apply discretionary accruals more intensively than value firms. In order to support the robustness of the findings, the Eckel model, was also applied. The same result was found for the Eckel model as for the Jones model. The results indicated that growth firms achieved a higher degree of income smoothing than value firms.

The effects of various confounding factors which are different between these two types of firms, such as size of the company, standard deviation of earnings, market capitalization and consecutive trend of earnings, were also investigated. The results indicated that income smoothing in growth firms is larger than in value firms, and also that other items, which are known as representatives of the risk, are larger for growth firms than for value firms.
\end{abstract}

Keywords: Income Smoothing, Value Firms, Growth Firms, Tehran Stock Exchange Market (TSE)

\section{Introduction}

In recent years, earnings management has become a controversial issue among investors and stockholders, and has also become a concern for the future (Bhattacharya et al., 2003; Becker et al., 1998). This issue has arisen partly because accounting standards allow managers to choose an appropriate accounting method from among other standards according to their discretion (Chong, 2006; Merchant, 1990). Furthermore, managers have access to private information about firms' true financial performance, although stockholders do not. Given the conflict of interests and incompatible objectives that might be prevalent between management and stockholders, according to the agency premises (Namazi, 1985), there is a possibility of income smoothing on the part of the managers.

Income smoothing by managers is also seen as a controversial practice in accounting, both by policy makers and regulators, and also by the investors of a firm who seek transparency in the manager's accountability for the firm's financial performance (DeBondt and Thaler, 1987). Hence, there is a vital desire to understand what situations will lead to such behaviour. In fact the major lines of inquiry seek to establish whether all firms alike are committed to smoothing income behaviour, or whether their behaviour depends on their ownership type? If that is the case, which types of firms are smoothing their income more than others? And what is (are) the effects of their smoothing behaviour?

The main aim of this study is to reply to the preceding inquiries. In effect, the major objectives are first to investigate the income smoothing behaviour of 'growth' and 'value firms' (see, Pawn, 2006) in the TSE market, to present a more comprehensive definition for value and growth firms, and to compare these two groups based on the level of management of their earnings. Second, to investigate their risk performance, and find out which type of company is the more risky for investment, by comparing risk factors that are prevalent between these two groups.

The significances of this study are as follows: 
1) It provides concise empirical evidence concerning the income smoothing behaviour of the firms. Thus, it offers valid research which is suitable not only for the TSE market, but also could be utilised for comparison of the results of other stock markets.

2) For the first time in Iran, it exhibits differences between the TSE 'value' and 'growth firms' with regard to income smoothing effects. This would also contribute to the extension of frontiers of knowledge at the international level.

3) It clearly demonstrates the confounding factors that are responsible for the risk determination of 'value' and 'growth firms'. This endeavour would also contribute to the extension of relevant knowledge in this growing field of accounting.

The remainder of this paper is organized as follows. Section 2 presents the theoretical structure and literature review. Section 3 contains the research design. Section 4 responds to the question, 'why should growth firms undertake more intensive smoothing?' Section 5 presents other factors of income smoothing and section 6 shows the results. Finally, section 7 presents the discussions and conclusions.

\section{Theoretical structure and literature review}

The theoretical framework of this study is based upon 'income smoothing' literature (Merchant, 1990; Pawn, 2006).

Chong (2006) suggests three main reasons why managers choose to smooth their earnings: first, to reach the benchmark level that has been established in the stock market, usually by analysts' forecasts. Second, to meet their own performance target, and third to avoid violations of debt contracts. However, a contemporary inquiry asks whether income smoothing behaviour is conducted by all firms?

In the financial literature (Fama et al., 1992; Little, 2006), firms are divided into two types: it is usual to define firms with high earnings yield or low market to book value as 'value firms', and those with low yield and high market to book value as 'growth firms'. Hejazi (2008) suggests the following investment approach for these firms:

1. Investment in growth model

\section{Investment in value model}

In the growth model, the growth stock is introduced and the large magnitude of earnings is allocated to investors and stockholders by investing in this sort of stock in the long-, but not in the short term. Therefore, investing in these stocks means having an appropriate rate of growth in the future, and stockholders should not expect a large amount of earnings in the short-term. Therefore, young, recently established firms are likely to consist of growth stock rather than any other type, because of their plans for research and future extension; hence stockholders can expect an appropriate rate of growth for these kinds of firms in the future, but not in the short-term. Another point about these stocks is the executive policy regarding the dividends. Executives of these firms do not tend to pay cash dividends, because they would like to retain their cash and reinvest it somewhere else. Finally, earnings from increases in the prices for the investors who invest in these stocks, would be greater than those from EPS.

In the value model, investors do not pay attention to the high future growth rates. The only matter that is important to investors is the firm's current value. Therefore, they attempt to purchase stock with a lower price than its intrinsic value, so investing in this model is more insured than investing in the growth model.

The distinction between growth and value firms has also been described by some accounting scholars and institutions. Basu (1999) documents that firms with a lower P/E ratio tend to have larger returns than firms with a higher $\mathrm{P} / \mathrm{E}$ ratio, and stock with a low $\mathrm{P} / \mathrm{E}$ is described as 'value stock' and stock with a higher $\mathrm{P} / \mathrm{E}$ ratio as 'growth stock'.

As mentioned earlier, a firm with a high earning yield or a low market to book value has been identified as a value firm, and for growth firms the direction is vice versa. Value stocks are considered to be more profitable than growth stocks, and this appears to be the case not only in the US (Fama and French, 1992), but also in foreign markets. There is a significant body of evidence that value firms consistently provide greater returns, whether this is measured on a monthly basis (Chan et al., 1991) or annually (Lakonishok et al., 1994), and after controlling for Price to Earnings (P/E), Book to Market (B/M), and cash flow multipliers.

Investment managers classify firms with high Earnings to Price (E/P), Book-to-Market equity (B/M) or Cash Flows to Price $(\mathrm{C} / \mathrm{P})$ as value stocks. They maintain that high $\mathrm{E} / \mathrm{P}, \mathrm{B} / \mathrm{M}$, or $\mathrm{C} / \mathrm{P}$ stocks have higher average returns than low $\mathrm{E} / \mathrm{P}, \mathrm{B} / \mathrm{M}$, or C/P stocks. Little (2006) describes the various characteristics of growth stocks as follows:

- A high magnitude of growth either historically or forecast.

- A high magnitude of ROE (Return on Equity). 
- The situation of EPS (Earnings per Share) in order to investigate that profit margin of pretax income should not be exceeding than five years mean and industry norm.

- Stock price needs to have at least doubled in the last five years.

He also describes the characteristics of value stocks as below:

- $\quad \mathrm{P} / \mathrm{E}$ ratio for such firms has to be at the very end of the $10 \%$ of all $\mathrm{P} / \mathrm{E}$ ratios' table.

- $\quad$ PEG (Price Earning to Growth ratio) has to be less than 1, which shows the price of the stock has been valued at less than the intrinsic value.

- Current assets have to be two times more than current liabilities.

- A small part of the equity would be allocated to liability.

Fama et al. (1992) suggest that identifying growth and value stocks is made easier by applying certain financial ratios. In this respect, some factors for counting value stocks are as below:

- $\quad \mathrm{P} / \mathrm{E}$ ratio is lower for value stocks

- $\quad \mathrm{D} / \mathrm{P}$ (Dividend to Price) is higher for value stocks

- $\quad \mathrm{S} / \mathrm{P}$ (Sale to Price) is higher for value stocks

- $\quad \mathrm{CF} / \mathrm{P}$ (Cash flow operating to Price) is higher for value stocks

- $\mathrm{B} / \mathrm{P}$ (Book value of assets to Price) is higher for value stocks

- $\mathrm{D} / \mathrm{E}$ (Debt to Equity) is lower for value stocks

- Beta is lower for value stocks

Although all of these ratios are important for identifying stock, the $\mathrm{B} / \mathrm{P}$ ratio is particularly useful for investors and analysts when identifying its value.

To identify the nature of stock as either value or growth, an index is required to capture several factors; Standard and Poors (S\&P), for example, on their website, list the following factors for identifying 'value stocks'.

- $\quad$ Dividend Yield

- $\quad$ Sales-to-Price $(\mathrm{S} / \mathrm{P})$

- $\quad$ Cash flow-to-Price $(\mathrm{C} / \mathrm{P})$

- $\quad$ Book-to-Price (B/P)

For growth stocks, $\mathrm{S} \& \mathrm{P}$ applies the following three items:

- 5 year EPS growth rate

- 5 year sales-per-share growth rate

- 5 year internal growth rate

The procedure for distinguishing between value and growth firms is as follows. First, a raw value, which is the arithmetic mean for each company, is calculated. Then they are standardized by dividing the difference between each stock's raw score and the mean of all the set by the standard deviation of all the set.

A growth score for each company is calculated as the mean of the standardized values of all growth factors. Similarly, the value score for each firm is calculated as the average of the standardized values of all value items.

Then scores are sorted based on their magnitude. The stocks at the top of the list with a high growth or low value score are known as 'growth stock'. They are the upper 33\% of the list.

The stocks at the bottom of the list exhibit a high value score or low growth score. Therefore, the bottom $33 \%$ of the list is known as 'value stocks'. The stocks in the middle of the list are neither growth stocks nor value stocks. This distinction is illustrated in table 1 :

Please insert table 1 here

For distinction between value firms and growth firms, another method has been introduced by Madhogarhia et al. (2009). This method computes stocks' geometric mean of the variables which are demonstrated in table 2.

Please insert table 2 here

In a recent analysis of income smoothing, Madhogarhia et al. (2009) utilized a sample of US firms from 1997 to 2001 and divided them into two separate groups: value firms and growth firms. Their results indicated that growth 
firms tended to manage their earnings more aggressively than value firms, both upwards and downwards. Information asymmetry was considered to be a relevant factor, and was much higher for growth firms than value firms.

Using this geometric index, the upper $30 \%$ of the ordered sample were categorized as 'growth firms' and the bottom $30 \%$ as 'value firms'. Due to the comprehensive nature, relevance and novelty of this approach, in this study we will apply this method as an indicator to identify 'growth' firms and 'value' firms.

\section{Research design}

\subsection{Research questions and hypotheses}

The main objective of this study is to investigate income smoothing behaviour among both 'value firms' and 'growth firms' which are listed in the TSE. Hence, this is an applied research in which the research plan is based upon the one-shot ex-post design only (Smith 2003).

In the present study, the following three questions are raised:

- Do TSE growth firms smooth their income more intensively than value firms?

- Is the characterization of income smoothing behaviour among the TSE growth and value firms robust under different techniques, specifically when the Jones and Eckel models are compared?

- Are TSE 'value firms' riskier than 'growth firms'?

In this study, we conjecture that growth firms have more incentive to smooth their earnings and this trend is conducted more aggressively than by value firms. Hence, this section looks for the reason why this trend should happen among growth firms.

Losses are known to affect stock prices more sharply in growth firms than value firms (DeBondt and Thaler, 1987). However, firms that report consecutive positive earnings (without reporting any loses in any year) suffer a large decline in their prices, if they report a loss for the first time during the period (DeAngelo, DeAngelo and Skinner, 1996). In this situation, as Derman and Berry (1995) indicate, analysts' overreaction to the recent actions and subsequent loses in earnings per share would affect the stock prices of growth firms more sharply than those of value firms.

These kinds of reactions appear to cause managers of growth firms to smooth their income more intensively than value firms in order to eliminate any large disappointment in earnings.

Hence, based on the preceding explanation and questions, the research hypotheses are stated as follows:

1. Growth firms tend to smooth their income more aggressively than do value firms.

2. The behaviour of value and growth firms with regard to income smoothing does not change regardless of whether the Jones model (1991) or the Eckel model (1981) is applied.

3. Value firms are riskier than growth firms.

\subsection{Population of the study}

The population of this study was all firms listed on the TSE. The Tehran Stock Exchange (TSE), which reopened in April 1968, is Iran's largest stock exchange. It is a member of the World Federation of Exchanges and a founding member of the Federation of Euro-Asian Stock Exchanges.It has been one of the world's best performing stock exchanges in recent years. Moreover it has been categorized as an emerging or "frontier" market. The number of firms listed on the TSE has also been increasing during the past 5 years, and reached about 445 in 2010.

In this study, the existing qualified firms for every single year between 2003 and 2007 were selected from all TSE firms, and no sampling method was applied. The number of firms in each year for the period of the study was different, but totalled 445 in 2010. Required data was gathered for these selected firms from the Tadbir Pardaz database.

\subsection{Models of income smoothing detection}

For statistical analysis, different techniques were applied. Since one of the aims of this study was to introduce value and growth firms' characteristics to investors, first a single geometric mean for all of the indicators (for example, $\mathrm{M} / \mathrm{B}$ and $\mathrm{P} / \mathrm{E}$, for each firm, as shown in table 2) was extracted and then these figures were compared to others in order to identify which were value and which were growth firms.

After categorizing firms into two different groups, the two-sample mean-comparison test (T-test), as a statistical tool, was applied to compare designated characteristics of some variables among these two groups. Following 
Madhogarhia et al. (2009), the T test was executed to compare the means of the growth firms and value firms. We will explain more about this later. In the next step, linear regression was used to identify variables' coefficients and variables' validity (at a significance level of 5\%) with respect to income smoothing action.

\subsubsection{The Jones model}

For this study, we first utilized the Jones Model (1991) to identify a firm as a smoother or non-smoother, where income smoothing is attributable directly to the discretion exercised in accruals (Madhogarhia et al., 2009, p.19).

The total accrual may thus be divided into two components: discretionary (unexpected) and nondiscretionary (expected), items. The nondiscretionary component is the level of accrual that would be expected for the activity of the firm; it is based on designated variables such as sales and level of investment in fixed assets.

The discretionary component of accruals reflects opportunities adopted by managers to smooth earnings and to signal private information. Indeed, as Healy (1985), Perry and Williams (1994), Defond and Jiambalvo (1994) and Shivakumar (2000), among others, note accounting standards are not entirely prescriptive and their flexibility can permit managers a degree of discretion in selecting different approaches to measurement; hence earnings management should be viewed as an ordinary action among firms.

The Jones model defines the expected Total Accrual as follows (Madhogarhia et al., 2009; p.9)

$$
\mathrm{TACC}_{\mathrm{jt}}=\alpha+\beta_{1} \Delta R E V_{j t}+\beta_{2} P P E_{j t}+\varepsilon_{j t}
$$

Where

$T A C C_{j t}=$ Total Accrual for firm $j$ in period $t$. It is equal to

$\{\{($ Current Assets - Cash $)$ - (Current Liability $)\}-($ Depreciation + Amortization expense $)\}$

$\triangle R E V_{j t}=$ difference in net revenue for firm $j$ between period $t-1$ and period $t$

$P P E_{j t}=$ gross property, plant and equipment for firm $\mathrm{j}$ in period $\mathrm{t}$

$\varepsilon_{\mathrm{jt}}=$ Residual terms

Consequently, the discretionary component of the accruals may be specified as follows:

$$
D A C C_{j t}=T A C C_{j t}-\mathrm{E}\left[T A C C_{j t}\right]
$$

where

$D A C C_{j t}=$ the discretionary accrual for the firm at time $\mathrm{t}$.

$\mathrm{E}\left[T A C C_{\mathrm{j} t}\right]=$ the predicted level of nondiscretionary accruals for the firm at time $\mathrm{t}$.

To find the predicted level of the nondiscretionary accruals, the linear regression model presented in (1), should have been computed. Consequently, predicted values, after inputting the coefficient in that regression, were calculated.

\subsubsection{The Eckel model}

As mentioned earlier, this study seeks to determine whether inferences regarding income smoothing differ significantly when based on the Jones model (1991) as opposed to the Eckel model (1981).For this reason, we applied the Eckle approach (1981), which relates the coefficient of variation in earnings to sales, as follows (Albrecht and Richardson, 1990,p. 717):

$$
\begin{gathered}
\mid C V \Delta \text { Earnings }|/| C V \Delta \text { Sales } \mid \\
C v=\frac{\Theta}{\mu}
\end{gathered}
$$

This ratio calculates the absolute value for the coefficient of variation (which is defined as the ratio of the standard deviation $\sigma$ to the mean $\mu$ ) of the earnings divided by the absolute value for the coefficient of variation of sales.

If the coefficient of variation of earnings is less than the coefficient of variation of sales, this suggests that firms are reporting a stream of earnings that is less volatile than would be expected given the behaviour of the gross revenues that give rise to those net earnings. In brief, if Eckel's index is less than 1, the firm is identified as a smoother, otherwise it is a non-smoother.

\subsubsection{Other factors of income smoothing}

It is insufficient to merely compare income smoothing behaviour among both groups; therefore in the next step other significant factors for comparison were considered. Madhogarhia et al. (2009) have identified the following influencing factors which differentiate growth firms from value firms. 
Please insert table 3 here

Here, as in Jensen (1976), the size of firm is identified as a factor which affects the rate of return. Also it is indicated that political processes have implications which determine accounting choices. Moreover they mentioned that political cost increases with the size of firm and also with a firm's risk level. Thus, managers of larger or riskier firms may have a greater incentive to decrease political costs. Hence, as expected, value firms tend to be more risky than growth firms, and we predict a larger size for value firms.

The second influential factor identified by Madhogarhia et al. (2009) is the extent of the analyst coverage. They maintain that growth firms will suffer much more than value firms with regard to earnings disappointments and negative EPS in a firm'. Hence, there will be larger incentives for growth firms' than for value firms' managers to apply income smoothing actions. Madhogarhia et al. (2009) also looked at institutional ownership because it reduces a mananger's ability to make abnormal accruals (Mitra, 2002, p.65). They also considered managerial ownership in the belief that higher levels of managerial ownership would cause lower levels of abnormal accruals and might have a substantial effect on growth firms when associated with higher levels of accruals (Warfield et al. 1995, p.26). In addition, they utilized Debt to equity ratio (D/E ratio), because a firm chooses different accounting approaches more intensively when it is closer to the bending debt covenants.

In addition, a capital structure comparison by applying the $\mathrm{D} / \mathrm{E}$ ratio indicates that value firms apply more debts than growth firms. This indicates relying more on equity financing (Sweeney, 1994, p.289) Finally, in the work of Madhogarhia et al. (2009), the type of the industry has been introduced as a set of the categorical dummy variables based on the 2-digit SIC codes to in order differentiate the performance of the growth firms from the value firms. Ironically, we utilized the preceding factors in this study.

\subsubsection{Risk factors}

Fama and French (1992) suggest that higher returns are associated with higher risk. Lakonishok, Shleifer, and Vishny (1994), however, indicate that increasing returns are related to both agency costs and investor's behaviour, andare not dependent only on risk. Hence in this study, a variety of different factors were considered as representatives for risk determination, including the number of unbroken strings of consecutive earnings increases (for example, Thomas et al., 2002), the standard deviation of earnings (for example, Devroye, 2000) and the market capitalization of the firm (Shubita et al., 2009).

\section{Research findings}

\subsection{Hypotheses results}

Table 4 shows descriptive statistics indicating the means of different factors for growth firms and value firms, and also the results for the hypotheses.

Please insert table 4 here

It is evident that growth firms demonstrate a significantly higher level of earnings management than value firms. As can also be clearly seen in table 4 , in the case of the absolute value of discretionary accruals, $A B S D A C C$ for growth firms is approximately 4 times greater than that for value firms. Hence, the first hypothesis of the study is accepted and the difference between the means is significant $(\mathrm{p}=0.047)$. In addition, growth firms also exhibit a much higher incidence of income smoothing ( $62 \%$ as compared to $8 \%)$. Thus, the second hypothesis is also accepted $(\mathrm{p}=0.007)$ because by changing the income smoothing detector from the one used in the Jones model to the one used in the Eckle model', the higher mean still dovetails with that of growth firms $(p=0.000)$.

With regard to the size of firms, the results demonstrate that growth firms tend to be smaller than value firms $(p=$ 0.049). Also it is found that growth firms on the Iranian stock exchange tend to be much smaller than value firms, and the market capitalization of equity and the standard deviation of earnings are also lower for growth firms than for value firms $(\mathrm{p}=0.002)$. Thus, value firms are riskier than growth firms, indicating that the third hypothesis can also be accepted.

\subsection{Regression analysis and its results}

In this part of the paper, some complementary cross-sectional analyses are presented in order to investigate the sensitivity of discretionary accruals with regard to different independent variables.

By computing the geometric means of the variables identified in table 1, we specified which firms were categorized as 'growth firms' and which were classified as 'value firms'. We then specified the result as 1 or 0 in the modeling of the discretionary accruals alongside other variables. The results are revealed in table 5.

Please insert table 5 here 
Consequently, to compare some of the indicators, measures such as the number of unbroken strings of consecutive earnings increase, firm size, market capitalization (share price times the number of shares outstanding of a public company), and standard deviation of the earnings between the two types of firm, we applied T test technique (see, e.g. Madhogarhia et al., 2009) by exerting the SPSS software. The level of significance for the entire study was set at $5 \%$.

In this study, the absolute value of the discretionary accruals was regressed on predictor variables using the following linear specification:

$$
A B S D A C C=\boldsymbol{\beta} 1 G R O W T H+\boldsymbol{\beta} 2 I S+\boldsymbol{\beta} 3 C T E+\boldsymbol{\beta} 4 S I Z E+\boldsymbol{\beta} 5 M C+\boldsymbol{\beta} 6 S D E+\boldsymbol{\varepsilon}
$$

SPSS (version 15) was used to complete the linear regression. The results are shown in table 6 .

Please insert table 6 here

Table 6 shows that, from 2005 onwards, there has been a significant relationship between income smoothing and accruals. The positive coefficient on income smoothing indicates that firms with a higher degree of income smoothing would have a greater tendency to exercise discretion in accrual accounting.

The consecutive trend in earnings illustrated a significant relationship with accruals in some years, and the positive coefficient indicated that such firms posed a greater tendency to exert accruals. For all the years except 2005, there was a significant relationship between discretionary accruals and the size of the firms, and the negative sign indicates that larger firms are associated with lower levels of discretionary accruals.

For representatives of risk, the result was almost the same. With respect to market capitalization for the whole period (except 2005 and 2007), the results are significant, and also for two out of three years, the coefficient is positive, hence it can be concluded that firms with a higher standard deviation of earnings or of higher risk, are associated with higher levels of discretionary accruals.

In the case of the standard deviation of earnings, the result is almost the same. For the whole period (except 2003 and 2006), the results demonstrate that there is a significant relationship between accruals and the standard deviation of earnings.

\section{Conclusions and discussion}

The main objective of this research was to investigate the income smoothing actions of firms in the TSE market, particularly among growth and value firms. The determination of risk performance among these two groups was another objective of the study.

It was found that 'growth firms' do apply accruals more intensively than 'value firms', which means that growth firms would utilize income smoothing more aggressively than value firms. These findings are consistent with the work of Madhogarhi et al. (2009).

The results also revealed that risk indicators for 'value firms' are larger than for 'growth firms'. Interestingly, this result for the TSE as an emerging market is the same as the result for other developing markets that have been previously studied (for example, Madhogarhia et al., 2009). Based on the Wikipedia dictionary, although between the years 2000 and 2003 there was no correlation between the TSE and other well known stock exchanges (such as those of New York and Tokyo) the TSE's performance between 2003 and 2007 moved a little closer to that of the leading markets.

In addition, changing the model used to measure income smoothing behaviour did not affect the results. That is, when analysed in terms of'both the Jones and Eckels' models, growth firms employed income smoothing behaviour more intensively than value firms. This may have happened because growth firms would attempt to apply income smoothing actions either by applying discretionary accruals or by applying nondiscretionary accruals. By considering only discretionary accruals, however, we merely investigated accounting exercises that happened based on the managers' discretion. But by considering the Eckel index, we had a deep look into the income statement to find out whether any smoothing process was happened in the firms either by applying discretionary accruals or by applying nondiscretionary accruals. The result indicated that growth firms' managers attempt to apply income smoothing actions either by withdrawing their discretion or exerting any true changes in the firms.

\section{Future suggestions}

This study suggests that investors should review a firm's financial situation before purchasing its stocks, to determine whether it is a 'value firm' or a 'growth firm'. As the results have revealed, buying stocks from a 'value firm' would be riskier than buying from a 'growth firm', although there is more expected profit in the short-term from value firms. Thus, investors must thoroughly consider the balance between a firm's potential risks and returns. 
This study also helps accounting regulators and the Iranian Bourse managers to establish contemporary rules with regard to TSE firm types. Introducing these terminologies and promulgations to investors and stockholders, would be useful to institutions, analysts and TSE individual stockholders. Finally, the findings will assist researchers to update the literature regarding types of firms and their performance, at both national and international levels.

Given the internal and external validity of this research, the implications and conclusions contribute to the progress of accounting and finance and could be extended to the international level and other stock markets.

This study also provides an incentive for future researchers to investigate the behaviour of different parts of accruals, whether working capital accruals, financing accruals, or non-current accruals such as the S\&P method, or any other method which can compare the two groups of firms. Also, future researchers might apply other methods to identify growth and value firms. Finally, the approach adopted by this study could be applied to other stock markets. This would extend current knowledge concerning these growing and related controversial accounting issues.

\section{References}

Albrecht, W. D., \& Richardson, F. M. (1990). Income Smoothing by Economy Sector. Journal of Business Finance \& Accounting, $\quad 17, \quad 713-730, \quad$ doi:10.1111/j.1468-5957.1990.tb00569.x, http://dx.doi.org/10.1111/j.1468-5957.1990.tb00569.x

Basu, S. (1999). Discussion of International Differences in the Timeliness, Conservatism, and Classification of Earnings. Journal of Accounting Research, 37(3), 89-99, doi:10.2307/2491346, http://dx.doi.org/10.2307/2491346

Becker, C., M., \& Subramanyan, K. R. (1998). The Effect of Audit Quality on Earnings Management. Contemporary Accounting Research 15, 1-24, doi:10.1111/j.1911-3846.1998.tb00547.x, http://dx.doi.org/10.1111/j.1911-3846.1998.tb00547.x

Bhattacharya, U., Daouk, H., \& Welker., M. (2003). The World Pricing of Earnings Opacity. The Accounting Review 83, 641-678.

Chan, L., \& J. Lakonishok. (2004). Value and Grow Investing: Review and Update. Financial Analyst Journal, 60, 71-86.

Chong, G. (2006). Is Income Smoothing Ethical? Journal of Corporate Accounting \& Finance, 18(1), 41-44.

Eckel, N. (1981). The Income Smoothing Hypothesis Revisited. Abacus, 17(1), 28-40, doi:10.1111/j.1467-6281.1981.tb00099.x, http://dx.doi.org/10.1111/j.1467-6281.1981. tb00099.x

DeAngelo, H., DeAngelo, L., \& Skinner, D. J. (1996). Reversal of Fortune: Dividend Policy and the Disappearance of Sustained Earnings Growth. Journal of Financial Economics, 40, 341-371.

DeBondt, W. F. M., \& Thaler, R. H. (1987). Further Evidence on Investor Overreaction and StockMarket Seasonality. Journal of Finance, 42(3), 557-581.

DeFond, M., \& Jiambalvo., J. (1994). Debt Covenant Violation and Manipulation of Accruals. Journal of Accounting and Economics, 17, 145-176, doi:10.1016/0165-4101(94)90008-6, http://dx.doi.org/10.1016/0165-4101(94)90008-6

Devroye, D., \& Freeman., R. (2000). Does Inequality in Skills Explain Inequality of Earnings Across Countries? Paper presented at the Harvard U. mimeo.

Dreman, D. N., \& M. A. Berry, M. (1995). Overreaction, Underreaction and the Low-P/E Effect. Financial Analysts Journal, 51(4), 21-30, doi:10.2469/faj.v51.n4.1917, http://dx.doi.org/10.2469/faj.v51.n4.1917

Fama, E. F., \& French., K. R. (1992). The Cross-Section of Expected Stock Returns. Journal of Finance, 47, 427-465, doi:10.2307/2329112, http://dx.doi.org/10.2307/2329112

Healy, P. M. (1985). The Effect of Bonus Schemes on Accounting Decisions. Journal of Accounting \& Economics, 7, 85-107, doi:10.1016/0165-4101(85)90029-1, http://dx.doi.org/10.1016/0165-4101(85)90029-1

Hejazi, R., \& Fatemi, M. (2008). Value Stock and Growth Stock. Journal of Hesabras, 42, 54-61.

Jensen., M. C., \& Meckling., W. (1976). Theory of the Firm: Managerial Behavior, Agency Costs and Capital Structure. Journal of Financial Economics, 3, 305-360.

Jones, J. J. (1991). Earnings Management during Import Relief Investigations. Journal of Accounting Research, 29, 193-228, doi:10.2307/2491047, http://dx.doi.org/10.2307/ 2491047

Lakonishok, S. V. (1994). Contrarian Investment Extrapolation and Risk. Journal of Finance, 50, 185-224, doi:10.2307/2329262, http://dx.doi.org/10.2307/2329262 
Little, K. (2006). Growth, Value Stocks Defined. Free Newsletter, a Part of the New York Times Company.

Madhogarhia, P., \& Kohers., S. N. (2009). Earnings Management Practices Among Growth and Value Firms. Applied Financial Economics, 19, 1767-1778.

Merchant, K. A. (1990). The Effects of Financial Controls on Data Manipulation and Management Myopia. Accounting Organization and Society, 15, 297-313, doi:10.1016/0361-3682(90)90021-L, http://dx.doi.org/10.1016/0361-3682(90)90021-L

Mitra, S. (2002). The Impact of Institutional Stock Ownership on a Firm's Earnings Management Practice: An Empirical Investigation. Dissertation, Louisiana State University.

Namazi, M. (1985). Theoretical Developments of Principal - Agent Employment Contract in Accounting: the State of the Art. Journal of Accounting Literature.(113-163).

Pawan, M., \& Theodor., K. (2006). Earnings Smoothing Among Growth and Value Firms. Southern Finance Association meeting in Destin.

Perry, S. E., \& Williams., T. H. (1994). Earnings Management Preceding Management Buyout Offers. Journal of Accounting and Economics, 18, 157-179, doi:10.1016/0165-4101(94)00362-9, http://dx.doi.org/10.1016/0165-4101(94)00362-9

Shivakumar, L. (2000). Do Firms Mislead Investors by Overstating Earnings before Seasoned Equity Offerings? Journal of Accounting and Economics, 29, 339-350, doi:10.1016/S0165-4101(00)00026-4, http://dx.doi.org/10.1016/S0165-4101(00)00026-4

Shubita, M. (2009). Discretionary Accruals, Market Capitalization, and Risk. eurojournals, 5, 1450-2889.

Smith, R., S. Lipin., \& Maj., A. (1994). How General Electric damps fluctuations in its annual earnings. Wall Street Journal, 3.

Sweeney, A. P. (1994). Debt-Covenant Violations and Managers' Accounting Responses. Journal of Accounting \& Economics, 17, 281-308, doi:10.1016/0165-4101(94)90030-2, http://dx.doi.org/10.1016/0165-4101(94)90030-2

Thomas, J. K., \& Zhang., H. (2002). Value-Relevant Properties of Smoothed Earnings.

Warfield, T. D., J. J. Wild, \& Wild., K. L. (1995). Managerial Ownership, Accounting Choices, and Informativeness of Earnings. Journal of Accounting \& Economics, 20, 61-91, doi:10.1016/0165-4101(94)00393-J, http://dx.doi.org/10.1016/0165-4101(94)00393-J

Table 1. The distribution of growth stocks and value stocks

\begin{tabular}{|l|}
\hline $\begin{array}{l}\text { Growth Stock } \\
\text { (upper } 33 \% \text { of index) }\end{array}$ \\
\hline $\begin{array}{l}\text { Stocks are not growth or value } \\
\text { (middle } 34 \% \text { of index) }\end{array}$ \\
\hline $\begin{array}{l}\text { Value Stocks } \\
\text { (lower 33\% of index) }\end{array}$ \\
\hline
\end{tabular}

Source: Standard and Poors

\section{Higher growth rank \\ Lower value rank \\ Higher value rank}

Lower growth rank

Table 2. Different variables applied for identifying the "Value firms" and "Growth firms". (Madhogarhia et al., 2009)

\begin{tabular}{|l|l|}
\hline $\mathrm{M} / \mathrm{B}$ & 1 \\
\hline $\mathrm{P} / \mathrm{E}$ & 2 \\
\hline $\mathrm{P} / \mathrm{CF}$ & 3 \\
\hline EPS growth & 4 \\
\hline Sales growth & 5 \\
\hline
\end{tabular}


Table 3. Factors effecting identifying growth firms and value firms

\begin{tabular}{|l|l|}
\hline Size of the firm & 1 \\
\hline Extent of the analyst coverage & 2 \\
\hline Institutional ownership & 3 \\
\hline Insider ownership & 4 \\
\hline Debt to equity ratio & 5 \\
\hline Industry & 6 \\
\hline
\end{tabular}

Source: Madhogarhia et al. (2009, p.1774)

Table 4. Comparison between growth and value firms

\begin{tabular}{|l|l|l|l|l|}
\hline & $\begin{array}{l}\text { Difference } \\
\text { between means }\end{array}$ & \multicolumn{2}{l|}{ Mean } & \\
\hline & t-test & Value & Growth & Sig. level \\
\hline $\begin{array}{l}\text { Absolute value of discretionary accruals } \\
(A B S D A C C)\end{array}$ & 2.00 & & & \\
\hline Income smoothing (IS) & 2.72 & 0.077 & 0.618 & 0.007 \\
\hline Consecutive trend of earnings (CTE) & 3.97 & 4.204 & 4.959 & 0.000 \\
\hline Size of the firm (SIZE) & 1.98 & $8,375,416$ & $1,789,067$ & 0.049 \\
\hline Market capitalization of equity $(M C)$ & 3.12 & 386,942 & 128,256 & 0.002 \\
\hline Standard deviation of earnings $(S D E)$ & 1.98 & 179,566 & 92,135 & 0.048 \\
\hline
\end{tabular}

Table 5. Dependent and independent variables of the study

\begin{tabular}{|l|l|l|}
\hline Abbreviation & Variable & \\
\hline ABSDACC & The absolute value of discretionary accruals (Jones) & The number of variable \\
\hline GROWTH & Growth firm 1, Value firm 0 & 1 \\
\hline$I S$ & $\begin{array}{l}\text { Eckel income smoothing } \\
\text { smoother = 1; zero otherwise }\end{array}$ & 2 \\
\hline$C T E$ & Number of unbroken strings of consecutive earnings increase & 3 \\
\hline$S I Z E$ & Size of the firm, i.e. 0.5 (assets + sales) & 4 \\
\hline$M C$ & Market capitalization of equity & 5 \\
\hline$S D E$ & Standard deviation of earnings & 6 \\
\hline
\end{tabular}

Table 6.The yearly regression results, from year 2003 to 2007

\begin{tabular}{|c|c|c|c|c|c|c|}
\hline Variable & Index & 2003 & 2004 & 2005 & 2006 & 2007 \\
\hline \multirow{3}{*}{ Growth } & $\beta 1$ & 117621 & -25042 & 116003 & 317239 & -298479 \\
\hline & $\mathrm{T}$ value & -2.39 & -0.26 & 0.44 & 1.73 & -1.38 \\
\hline & Sig. & 0.021 & 0.793 & 0.655 & 0.047 & 0.172 \\
\hline \multirow{3}{*}{ Income smoothing } & $\beta 2$ & -18187 & 7849 & 84308 & 41700 & 99089 \\
\hline & $\mathrm{T}$ value & -0.37 & 0.07 & 0.29 & 0.22 & -0.18 \\
\hline & Sig. & 0.706 & 0.936 & 0.007 & 0.008 & 0.008 \\
\hline \multirow{3}{*}{$\begin{array}{l}\text { Consecutive trend of } \\
\text { earnings }\end{array}$} & $\beta 3$ & -11387 & 22847 & 47183 & 48060 & -143175 \\
\hline & $\mathrm{T}$ value & -0.77 & 0.71 & 0.45 & 0.89 & -1.53 \\
\hline & Sig. & 0.444 & 0.047 & 0.649 & 0.037 & 0.132 \\
\hline \multirow{3}{*}{ Size of firm } & $\beta 4$ & -0.184 & 0.035 & 0.027 & -0.023 & -0.122 \\
\hline & $\mathrm{T}$ value & -3.71 & 0.55 & 0.41 & -2.25 & -8.68 \\
\hline & Sig. & 0.000 & 0.578 & 0.679 & 0.028 & 0.000 \\
\hline \multirow{3}{*}{ Market capitalization } & $\beta 5$ & 0.236 & -0.408 & -0.197 & 0.712 & 0.666 \\
\hline & $\mathrm{T}$ value & 1.88 & -4.47 & -0.68 & 5.01 & 0.91 \\
\hline & Sig. & 0.047 & 0.000 & 0.495 & 0.000 & 0.364 \\
\hline \multirow{3}{*}{$\begin{array}{l}\text { Standard deviation of } \\
\text { earnings }\end{array}$} & $\beta 6$ & -0.017 & -1.311 & 7.744 & -1.165 & 3.329 \\
\hline & $\mathrm{T}$ value & -0.37 & -1.86 & 4.32 & -1.41 & 7.10 \\
\hline & Sig. & 0.713 & 0.049 & 0.000 & 0.162 & 0.000 \\
\hline
\end{tabular}

